\title{
Purification and Some Properties of Milk-clotting Enzyme from Aspergillus niger
}

\author{
By H. G. OSMAN, A. F. ABDEL-FATTAH AND \\ SOUHAIR S. MABROUK \\ Laboratory of Microbiological Chemistry, \\ National Research Centre, Dokki, Cairo, U.A.R. \\ (Accepted for publication 15 August 1969) \\ SUMMARY
}

\begin{abstract}
The electrophoretic separation of partially purified milk-clotting enzyme from Aspergillus niger no. 58 with $0.02 \mathrm{M}$-acetate buffer showed four protein components. The milk-clotting enzyme fraction constituted the major part of the preparation and exhibited the highest milk-clotting activity and the lowest proteolytic action. The course of proteolysis in the first stage of the enzymic action was similar to that of animal rennin. The enzyme action was optimal at $50^{\circ}$ and $\mathrm{pH} 5.8$.
\end{abstract}

\section{INTRODUCTION}

When casein is transformed into paracasein by the action of animal (calf) rennin, a glycomacropeptide (NPN) is split off (Alais, Moquot, Nitschmann \& Zahler, 1953). This glycomacropeptide contains about $14 \%$ N-acetylneuraminic acid (NANA; Nitschmann, Wissman \& Henzi, 1957; Brunner \& Thompson, I959; Jollès \& Alais, 1960; Alais \& Jollès, I96I). Koning, Jenness \& Wijnand (1963) stated that all the NANA present in casein was set free by the action of animal rennin, as NPN-bound NANA. Little is known, however, about the action of microbial milk-clotting enzymes. The aim of the present work was to study the mode of action of the milk-clotting enzyme preparations from Aspergillus niger isolate no. 58 on casein and the release of NPN-bound NANA. Further purification of the enzyme preparation by electrophoresis was performed.

\section{METHODS}

Organism. Aspergillus niger isolate no. 58, which was isolated locally and shown to be a potent organism for producing active milk-clotting enzyme (Osman, AbdelFattah, Abdel-Samie \& Mabrouk, 1969), was used. Cultivation was done as described by Osman et al. (1969).

Culture medium. This was composed of corn-steep liquor $(2 \%, w / v)+$ lactose $(\mathrm{I} \%, \mathrm{w} / \mathrm{v})$ in water.

Preparation of milk-clotting enzyme. After incubation for 3 days at $30^{\circ}$, the culture filtrate was precipitated with 2 vol. ice-cold acetone. After drying overnight over $\mathrm{P}_{2} \mathrm{O}_{5}$, the precipitate was dissolved in a known volume of $0.02 \mathrm{M}$-acetate buffer $\left(\mathrm{pH}_{4} \cdot 0\right)$.

Casein. Isoelectric casein (Difco, Detroit, Michigan, U.S.A.) was used.

$N$-Acetylneuraminic acid. This was a preparation of Koch-Light Lab., Colnbrook, Bucks., England. 
Measurement of milk-clotting activity. This was done by the method of Berridge (I952); $2.5 \mathrm{ml}$. of buffered enzyme sample were incubated with $10 \mathrm{ml}$. reconstituted dry skim milk ( $12 \mathrm{~g}$. dry skim milk/ $100 \mathrm{ml}$. $0.0 \mathrm{I} \mathrm{M}-\mathrm{CaCl}_{2}$ ) at $40^{\circ}$ and the clotting-time recorded. One unit of enzyme activity was taken to be that which clotted $10 \mathrm{ml}$. milk in 10 min. at $40^{\circ}$.

Estimation of gelatinase activity. This was done according to the method of Bergkvist (1963) for proteases of Aspergillus oryzae (see Osman et al. 1969). The electropherogram was cut longitudinally and one part was stained with Amido black Io B, the corresponding portion of the protein band on the unstained part was cut off and eluted with citrate + phosphate buffers of different $\mathrm{pH}$ values. The enzyme samples of the different fractions were adjusted to contain equal amounts of protein (enzyme).

Estimation of protein content. This was done by the method of Lowry, Rosebrough, Farr \& Randall (I95I).

Determination of $N$-acetylneuraminic acid (NANA) in glycomacropeptide $(N P N)$. The investigation of NPN-bound NANA due to the action of the clotting enzyme on milk was done by the method of Koning et al. (1963) as follows. To Io ml. milk, at $40^{\circ}$ in a constant temperature water bath, samples $(2.5 \mathrm{ml}$.) of enzyme solution at the same temperature were added and after different periods of time the enzyme was inactivated by heating for $10 \mathrm{~min}$. in an $80^{\circ}$ water bath. The paracaseinate was then precipitated by adding enough $75 \%(\mathrm{w} / \mathrm{v})$ trichloroacetic acid solution to give a final concentration of $12.5 \%$. The paracaseinate was then removed by centrifugation, the precipitate washed with $\mathrm{I} 2.5 \%$ trichloroacetic acid and the washings added to the first supernatant fluid. Samples from the supernatant fluids were hydrolysed in $0 . \mathrm{I} \mathrm{N}-$ $\mathrm{H}_{2} \mathrm{SO}_{4}$ for $\mathrm{I} \mathrm{hr}$ at $80^{\circ}$. The NANA content of the supernatant fluid represented both free NANA and NANA bound to peptides. Unbound NANA was obtained by determination in the supernatant fluid before hydrolysis.

$\mathrm{N}$-Acetylneuraminic acid was determined by the thiobarbituric acid assay method of Warren (1959). A standard curve was constructed by using different concentrations of $\mathrm{N}$-acetylneuraminic acid (0.01 to $0.05 \mu$ mole $/ 0.2 \mathrm{ml}$.).

Electrophoresis of milk-clotting enzyme preparation. Paper electrophoresis was done with the Elphor apparatus and acetate buffer $\left(\mathrm{pH}_{4}{ }^{\circ}, \mu=0.04\right)$ for the separation of fractions from partially purified enzyme preparations. A potential ranging from I50 to $300 \mathrm{~V}(0.2 \mathrm{~mA} / \mathrm{strip})$ was applied in the experiments at room temperature. The enzyme solution used was a sample of a preparation concentrated by precipitation of culture filtrate with 2 vol. of acetone. Staining was with Amido black Io B (Grassman \& Hannig, 1950). Enzyme-bearing protein fractions were scanned with an Extinction Recorder Scanner (Carl Zeiss, Jena). The proportions of each fraction were calculated on the basis of the dry weights of scanned areas.

\section{RESULTS}

Electrophoretic separation and mode of action of the fungal milk-clotting enzyme. The paper electrophoretic separation of the milk-clotting enzyme, using $0.02 \mathrm{M}$-acetate buffer $\left(\mathrm{pH}_{4}{ }^{\circ}\right)$ showed four components, A, B, C, D. All the electrophoretically separated components moved towards the cathode; component $\mathrm{A}$ was the slowest and remained near the starting line; while fractions $B, C$ and $D$ were nearer the cathode. By scanning the electropherograms, fraction A was found to constitute two-thirds the 
protein content of the partially purified enzyme preparation, and contained most of the milk-clotting activity but very little proteolytic activity. The other fractions showed little clotting activity and more proteolysis (Tables $I, 2)$.

Table I. Aspergillus niger no. 58. Milk-clotting activity of crude enzyme, partially purified enzyme and electrophoretically-separated fractions

\begin{tabular}{|c|c|c|c|c|c|c|}
\hline \multirow[b]{2}{*}{ Enzyme sample } & \multirow{2}{*}{$\begin{array}{l}\text { Culture } \\
\text { filtrate }\end{array}$} & \multirow{2}{*}{$\begin{array}{l}\text { Partially } \\
\text { purified } \\
\text { enzyme }\end{array}$} & \multicolumn{4}{|c|}{$\begin{array}{l}\text { Electrophoretic fractions of the } \\
\text { partially purified enzyme }\end{array}$} \\
\hline & & & A & B & $\mathrm{C}$ & D \\
\hline Clotting-time (min.) & $8 \cdot 50$ & $5 \cdot 00$ & 12 & 1260 & 900 & 960 \\
\hline $\begin{array}{l}\text { mg. protein } / 2.5 \mathrm{ml} \text {. enzyme } \\
\text { sample }\end{array}$ & $6 \cdot 65$ & $3 \cdot 70$ & $1 \cdot 3$ & 0.16 & 0.13 & 0.1 \\
\hline $\begin{array}{l}\text { Units enzyme/mg. protein } \\
\% \text { relative activity }\end{array}$ & $\begin{array}{l}0.17 \\
100 \cdot 0\end{array}$ & $\begin{array}{r}0.54 \\
317.60\end{array}$ & $\begin{array}{r}0.64 \\
376 \cdot 50\end{array}$ & $\begin{array}{r}0.05 \\
29.40\end{array}$ & $\begin{array}{r}0.09 \\
52.90\end{array}$ & $\begin{array}{r}0.1 \\
85.8\end{array}$ \\
\hline
\end{tabular}

Table 2. Aspergillus niger no. 58. Proteolytic activity (gelatinase) of the electrophoretically separated fractions of the milk-clotting enzyme at different $\mathrm{pH}$ values

\begin{tabular}{|c|c|c|c|c|}
\hline & \multicolumn{4}{|c|}{ Fraction } \\
\hline & A & B & $\mathrm{C}$ & D \\
\hline $\mathrm{pH}$ & \multicolumn{4}{|c|}{$\begin{array}{l}\text { Proteolytic activity (\% decrease in } \\
\text { relative viscosity of gelatin) }\end{array}$} \\
\hline $2 \cdot 2$ & $3 \cdot 80$ & $4 \cdot 60$ & I I $\cdot 30$ & 0.0 \\
\hline 4.0 & $2 \cdot 80$ & 10.66 & $5 \cdot 40$ & 10.5 \\
\hline $6 \cdot 0$ & $2 \cdot 56$ & 27.00 & $4 \cdot 10$ & 18.0 \\
\hline $8 \cdot 0$ & 0.0 & 15.66 & 0.0 & $24 \cdot 0$ \\
\hline
\end{tabular}

Table 3. Aspergillus niger no. 58. The $N$-acetylneuraminic acid $(N A N A)$ in glycomacropeptide $(N P N)$ released during enzymic reactions with milk-clotting enzyme preparation and electrophoretic fractions of it

Enzyme sample

Partially purified enzyme

Fraction A

Fraction B

Fraction C

Fraction D

mg. protein/
$2.5 \mathrm{ml}$.
3.70

$1 \cdot 30$

$0 \cdot 16$

0.13

$0 \cdot 10$
Clotting-time (min.)

$5 \cdot 0$

12.0

I $260^{\circ} 0$

$900 \cdot 0$

$960 \cdot 0$
Time of reaction $\mu$ mole NANA/ (min.)

$0.2 \mathrm{ml}$.

$\begin{array}{rr}7.0 & 0.013 \\ 10.0 & 0.013 \\ 20.0 & 0.013 \\ 30 \cdot 0 & 0.013 \\ 8.0 & 0.011 \\ 12.0 & 0.015 \\ 15.0 & 0.015 \\ 25.0 & 0.015 \\ 1020 \cdot 0 & 0.007 \\ 260 \cdot 0 & 0.010 \\ 440.0 & 0.023 \\ 560 \cdot 0 & 0.035 \\ 780 \cdot 0 & 0.008 \\ 900.0 & 0.011 \\ 960.0 & 0.017 \\ 200.0 & 0.023 \\ 300 \cdot 0 & 0.002 \\ 960 \cdot 0 & 0.007 \\ 200.0 & 0.011\end{array}$


When following proteolysis before and after milk clotting, a progressive increase in free NANA was noticed with all fractions until the stage of clotting took place. Thereafter, no proteolysis was observed with fraction A while proteolysis continued with the other fractions (Table 3). Thus, fraction A was characterized by its limited proteolytic action on milk casein. On the other hand, the partially purified enzyme sample containing the mixture of four fractions did show the same amounts of liberated NPN-bound NANA as with fraction A, indicating the presence of the other fractions in minute amounts only. When repeating the experiment with fraction $\mathrm{A}$ and isoelectric casein no free NANA was found in the supernatant fluid obtained, as a result of the enzyme action. Hydrolysis of the supernatant fluid gave the same values for free NANA as recorded in Table 3. Thus, the NPN liberated by the microbial enzyme contained only bound NANA. The microbial milk-clotting enzyme (fraction A) was thus similar to animal rennin with respect to the course of proteolysis and the type of NPN released (Koning et al. 1963).

Properties of the milk-clotting enzyme fraction $A$. Gradual increase in the clotting time occurred with increase in substrate concentration from 12 to $30 \mathrm{~g}$./ $100 \mathrm{ml}$. This retardation might have been due to the increase in the viscosity of the reaction mixture. The addition of calcium chloride minimized that effect. The rate of enzymic phase, and hence clotting, seemed to depend on the concentration of enzyme. An optimum temperature of $50^{\circ}$ and an optimum $\mathrm{pH}$ of 5.8 were found for the milk-clotting activity of the enzyme. The same $\mathrm{pH}$ value was found optimal for a milk-clotting enzyme isolated from Aspergillus candidus (Veselov, Tipograf \& Petina, 1965). The stability of the enzyme towards heat depended on the $\mathrm{pH}$ value. Generally, the enzyme was more stable at $\mathrm{pH} 3.4$ and gradually lost its activity with increase of $\mathrm{pH}$ value. Thus,

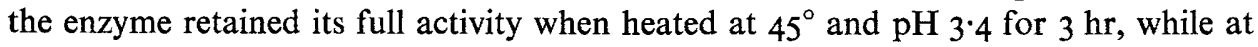
the same temperature for $\mathrm{I} \mathrm{hr}$ and at $\mathrm{pH} 5^{\circ}$, complete loss of activity occurred.

The effect of iodoacetic acid, maleic acid, ascorbic acid, potassium cyanide, mercuric chloride, cysteine hydrochloride, iodine and copper sulphate on the milk-clotting activity was examined. This was done by incubating, for $15 \mathrm{~min}$. at $40^{\circ}, 2.5 \mathrm{ml}$. buffered enzyme solution ( $(0.02 \mathrm{M}$-acetate buffer, $\mathrm{pH} 4.0$ ) containing $0.0 \mathrm{I} \mathrm{M}$ or $0.00 \mathrm{I} \mathrm{M}$ of test substance. After incubation, the enzyme solution was added to Io ml. milk containing the normal amount of $\mathrm{CaCl}_{2}$. The results showed that such agents had not affected the process of clotting. However, it seems that the activity decreased with reducing agents and increased with oxidizing agents.

The authors express their thanks to Mr M. Abdel-Samie, Assitant Research Worker in this laboratory, for his valuable advice.

\section{REFERENCES}

Alais, C., Mocquot, G., Nitschmann, H. S. \& Zahler, P. (1953). Rennet and its effect on casein in milk. VII. The splitting of non-protein nitrogen from casein by rennet, and its relation to the primary reaction in rennet coagulation of milk. Helv. chim. Acta 36, 1955.

Alais, C. \& Jollès, P. (I96I). Comparative study of the caseinoglycopeptides obtained after rennin digestion of the caseins of the milk of cow, sheep and goat. II. Study of the non-peptide part. Biochim. biophys. Acta 51, 315.

Bergkvist, R. (1963). The proteolytic enzymes of Aspergillus oryzae. I. Methods for the estimation and isolation of the proteolytic enzymes. Acta chem. scand. 17, 1521. 
BERRIDGe, N. J. (1952). Some observations on the determination of the activity of rennet. Analyst, Lond. 77, 57.

BRunNeR, J. R. \& Thompson, M. P. (1959). Some characteristics of the glycomacropeptide of casein -a product of the primary rennin action. J. Dairy Sci. 42, $188 \mathrm{I}$.

Grassman, W. \& HaNNIG, K. (I950). A quantitative amino-acid determination by a combination of electrophoresis and chromatography, with examples of applications. Naturwissenschaften 37, 397.

Jollès, P. \& Alais, C. (1960). Glycopeptide obtained by rennin on k-casein of cow's milk. C.r. hebd. Séanc. Acad. Sci., Paris 251, 2605.

Koning, P. J. DE, Jenness, R. \& WiJnand, H. P. (1963). Some aspects of the determination of $N$ acetylneuraminic acid and its use for the comparison of the action of heat and rennin on casein. Ned. Melk-Zuiveltijdschr. 17, 532.

Lowry, O. H., Rosebrough, N. J., Farr, A. L. \& Randall, R. J. (1951). Protein measurement with the Folin phenol reagent. J. biol. Chem. I93, 265.

NitschmanN, Hs., Wissman, K. \& Henzi, R. (1957). Concerning a glycomacropeptide, a cleavage product of casein, obtained by the action of rennet. Chimia $\mathbf{1 1}, 76$.

Osman, H. G., Abdel-Fattah, A. F., Abdel-Samie, M. \& Mabrouk, S. S. (I969). Production of a milk-clotting enzyme preparation by Aspergillus niger and the effect of various factors on its activity. J. gen. Microbiol. 59, 125.

Veselov, I. Ya., Tipograf, D. YA. \& Petina, T. A. (1965). Aspergillus candidus as a producer of rennin. Prikl. Biokhim. Mikrobiol. $\mathbf{1}, 52$.

WARren, L. (1959). The thiobarbituric acid assay of sialic acids. J. biol. Chem. 234, 197I. 